DOI: $10.17516 / 1997-1370-0331$

УДК 81.33

\title{
Highly Likely: Anthropological Patterns in Perceptions of Probability
}

\author{
Valentina A. Kononova* \\ Siberian Federal University \\ Krasnoyarsk, Russian Federation
}

Received 09.08.2017, received in revised form 23.08.2018, accepted 06.09.2018

\begin{abstract}
The paper addresses relations between probability as a measure of the likelihood that an event will occur and pragmatic functions of «highly likely» hedging device in modern political, legal and social media discourses, particularly in the context of infamous Scripal case in Great Britain in March 2018. On the other hand, «highly likely» pattern is viewed as anthropological linguistic phenomenon in virtual interaction between two high-profile politicians - the British Prime Minister Theresa May and the Foreign Minister of Russia Sergey Lavrov in a situation of political accusation (the native speaker) and diplomatic defense (the actor alternates between two languages). The paper offers an approach to understanding the relationship between social processes and linguistic forms. Besides, five modern language corpora provided database for study of randomly selected contexts («highly likely» concordance), that allows to figure out several reasons of «highly likely» phrases to hedge which do not necessarily relate to probability, but may be applied to avoidance, uncertainty, imprecision, mitigating criticism, and modifying.
\end{abstract}

Keywords: linguistic anthropology, probability, highly likely, hedging, Scripal case, Sergey Lavrov, Theresa May, fact vs opinion.

Research area: linguistics, corpus linguistics, linguistic anthropology

Citation: Kononova, V.A. (2018 online). Highly likely: anthropological patterns in perceptions of probability. J. Sib. Fed. Univ. Humanit. soc. sci., 2022 15(10), 1524-1532. DOI: 10.17516/19971370-0331

(C) Siberian Federal University. All rights reserved

* Corresponding author E-mail address: v.kononova@mail.ru 


\title{
Highly likely: антропологические паттерны восприятия вероятности
}

\author{
B.А. Кононова \\ Сибирский федеральный университет \\ Российская Федераџия, Красноярск
}

\begin{abstract}
Аннотация. В статье рассматриваются отношения между вероятностью как мерой возможности возникновения тех или иных событий и прагматическими функциями лингвистической хеджирующей конструкции «highly likely» в современных политических, правовых и социальных медиа-дискурсах, особенно в контексте пресловутого дела Скрипалей в Великобритании в марте 2018 года. Лингвистический феномен «highly likely» в контексте виртуальной конфронтации двух высокопоставленных политических деятелей современности - британского премьерминистра Т. Мэй и российского министра иностранных дел С.В. Лаврова рассмотрен в антропологических рамках как ситуация политического обвинения на высшем уровне (Мэй, английский язык) и дипломатической защиты (Лавров, переключение английского и русского языковых кодов). Рассматриваемые примеры позволили усилить понимание взаимосвязей между социальными процессами и лингвистическими формами. Контексты из пяти современных языковых корпусов позволили выявить ряд прагматических функций хеджирования, которые не обязательно относятся к области вероятности, но могут быть применены к ситуации уклонения, неопределенности, неточности, смягчения критики и модификации.
\end{abstract}

Ключевые слова: лингвистическая антропология, вероятность, «highly likely», хеджирование, дело Скрипалей, Сергей Лавров, Тереза Мэй, факт и мнение.

Научная специальность: 10.02.00 - лингвистика, корпусная лингвистика, лингвистическая антропология.

\section{Introduction}

Probability is increasingly important for understanding of the world. Successfully working your way through probability issues means understanding some basic rules of probability along with continuous probability distributions in various fields. Many scholars at all times (Kerrich, 1946; Feller, 1968; Jaynes, 2003; etc.) were thrilled with the idea of probability. «We use probability when we want to make an affirmation, but are not quite sure,» - the words belong to John Randolph Lucas, a modern British philosopher. Bertrand Russell, a mathematician and Noble laureate pointed out, «Probability is the most important concept in modern science, especially as nobody has the slightest notion what it means.»

There are many interpretations of the word probability which involve talk about chances, odds, uncertainty, prevalence, risks, expectancy, etc. A complete discussion of these interpretations mostly refers to the areas of mathematics (probability theory, Bayesian probability), philosophy (foundations of probability), religion (theistic probability), etc. For many areas of study, probability is considered to be the measure of the likelihood of an event happening. Probability is quantified as a number between 0 and 1 , with 0 indicating impossibility and 1 indicating certainty. The higher the probability of an event, the more likely it is that the event will occur. An elegant example is the tossing of a fair coin, a popular way of picking a random winner, where the two outcomes - «heads» and «tails» - are both equally probable, with no other options are possible.

The word probability itself derives from the Latin probabilitas, which can also mean probity, 
or soundness, a measure of the authority of a witness in a legal case in Europe, and often correlated with the witness's nobility. The old usage differs from the modern meaning of probability, which, by contrast, is a measurement tool of empirical evidence, and is arrived at from inductive reasoning and statistical inference.

In the English language, the ways to express probability, to say the least, are widely studied, described (Palmer, 1979, 2001; Carter, McCarthy, 2006; Crystal, 1997, etc.) and broadly presented: first of all, these are modal verbs (might, must, cannot, etc.), as well as words and phrases that express possibility and probability (maybe, it's possible, etc.). They also include adjectives likely and unlikely which are similar in meaning but different grammatically. Some adverbs such as very, quite, highly and extremely go before likely and unlikely to make their meaning, and thus, probability, sound stronger.

On the other hand, all these language units belong to the complex semantic category of hedges, which is associated with unclarity or fuzziness (Lakoff, 1972: 195): «Hedging is a rhetorical strategy. By including a particular term, choosing a particular structure, or imposing a specific prosodic form on the utterance, the speaker signals a lack of a full commitment either to the full category membership of a term or expression in the utterance (content mitigation), or to the intended illocutionary force of the utterance (force mitigation).» (Bruce, 2010: 201).

\section{Probability in modern contexts: the Scripal case}

Probability is a frequent visitor in today's fast-paced and complex political environment, where politicians, newsmakers and news consumers often make rapid-fire statements and judgments. International agendas can give strong momentum for unexpected speculations over supposedly common language uses and lead to empirical or critical discourse analysis, and more than that to the interests of linguistic anthropology on what was said or reported. Linguistic anthropology is known to assume that the human language faculty is a cognitive and a social achievement that provides the intellectual tools for thinking and acting in the world (Duranti, 2002: 8899), and the interface between language and political resources leads to the study of the linguistic dimensions of power and control.

In March 2018, the British government accused Russia of attempted murder of a former double agent Sergei Skripal and his daughter who were poisoned in Salisbury, England, with a so called Novichok nerve agent, according to the official UK sources and the Organisation for the Prohibition of Chemical Weapons (OPCW). The Prime Minister Theresa May, speaking in the British parliament, delivered a statement on the incident: «...the Government has concluded that it is highly likely that Russia was responsible for the act against Sergei and Yulia Skripal.» (PM Commons statement on Salisbury...; italics added). For politicians, language is always a powerful tool to loose or to win, their language is often vague, imprecise, or general, they tend to protect themselves against any future possible criticism (Taweel et al., 2011: 169). The political scandal turned into a series of measures and speculations, including those around «highly likely» words. Name a few, the Russian Foreign Minister Sergey Lavrov speaking exclusively to HARDtalk's Stephen Sackur, said: «You have hard talk, ... we want hard facts. And «highly likely» is really ridiculous... [It is] a new invention of the British diplomacy to describe why they punish people - because these people are highly likely guilty, like in Alice in Wonderland by Lewis Carroll - when he described a trial. And when they discovered that the jury could be engaged, then the King said «Let's ask the jury» and the Queen shouted «No jury! Sentence first - verdict afterwards.» That's the logic of highly likely.» (Lavrov, March 2018). In numerous interviews and official comments, Lavrov switches English-Russian language codes, talks again and again about the «infamous «highly likely» approach» (Lavrov, May 2018) and does not mince his words: «Now this «highly likely» thing is becoming contagious. The assertion... in the same vein: «highly likely» and we are not given any single fact.» (Lavrov, July 2018). In this manner, it became impossible to get different actors from different cultures to agree upon the same perception on the «highly likely» degree of probability. 
In the meantime, Russian social network users created a hashtag \#HighlyLikelyRussia to highlight their attitude to the claims of the British Prime Minister, which indicated that «highly likely» statements do not add trust in the received information (https://twitter.com/hashtag/ highlylikelyrussia; https://www.instagram.com/ explore/tags/highlylikelyrussia/?hl=enl).

However, some news consumers attempt to give a deeper insight into the English language peculiarities in sense of the "highly likely» expression. Boris Maksimov of the BBC's Russian Service makes out that the Englishman's «highly likely» means that he is $99.99 \%$ sure that what happened really took place (Maksimov, 2018). Nikolay Voronin, the BBC's Multimedia Editor, lumps together factual and opinion statements and revoices that many language forms «do not have adequate translation into Russian due to the difference of cultures» and in the first instance, the «Great British Art of Understatement». In his blog, Voronin goes on that «when an Englishman says «highly likely», it should be understood unambiguously: it is no «possible», but confirmed, or dead right, absolute truth, all the facts indicate that.» (Voronin, 2018).

Still, not everyone sees problems in such cases, and answering the question «What is the best approach to inter-culturality in a society with people from different origins and languages?», Romero-Trillo cites Istvan Kecskes: «...intercultural communication [is] a normal successand-failure process rather than a collision of cultures.» (Romero-Trillo, 2014: 621).

At the same time, a Canadian educator Jim Miles, in his comments on the UN Security Council discussion about the Skripal case, sees a legal dodge and lack of alternate explanations in the «official» UK theory, and advances a different opinion about the "highly likely» use in this context, that is «a reflection of the British judicial system in that «only a court can finally determine culpability» but the case has not reached the court yet (Miles, 2018).

In 2018, outside the Skripal context, the Sherman-Kent School, USA, provided the study based on the data gathered from Reddit's/r/samplesize community, that is opinions of people of all ages from around the globe (Perceptions of probability and numbers, 2018) (Fig. 1). The study revealed 17 overlapping degrees of probability perceptions, from the degree «chances are slight» to «almost certainly», with «highly likely» on the sixteenth position.

In summary, the "highly likely» can give a substantial food for thought not only for politicians, and wide public, but for linguistic anthropologists as well. Language plays a crucial role in mediating differences in power between speakers. In an anthropological approach, language is seen as permeable to social situations and social roles while at the same time helping to define those situations and roles (Duranti, 2002: 8902).

\section{Facts vs opinions}

These findings and speculations lead to the simple question: How likely is highly likely? $99.99 \%$ ? Less? More? What is the degree of probability? Does probability here measure the real, physical tendency of something to occur, i. e. facts, or is it a measure of how strongly one believes it will occur, i. e. opinions, or does it draw on both these elements? Being able to distinguish between fact and opinion helps to discern the reliability of the acquired bits of information, which can be presented as facts when they may be just an opinion. It may seem at first that differences are easy to recognise, however, it is not the case. The main distance between fact and opinion is the capacity to be proved or disproved by objective evidence (Mitchel et al., 2018: 4). In general, fact and opinion can be compared by a number of references: type of text, verifiability, objectivity, changeability (Table 1).

Coming back to the British Prime Minister' s statement, it can be regarded as a piece of official information presented as having objective reality, on the one hand, and still has not been proved with evidence, does not look neutral and unchangeable, particularly because of the «highly likely» phrase, on the other side. The phrase as such might belong to the complexity of the meanings of the hedging devices and mean that the author wants the public to know that by now she does not claim to have the final word on the subject. She is confidently uncertain, and intentionally uses noncommittal and ambiguous statement with a very high perception of probability. 


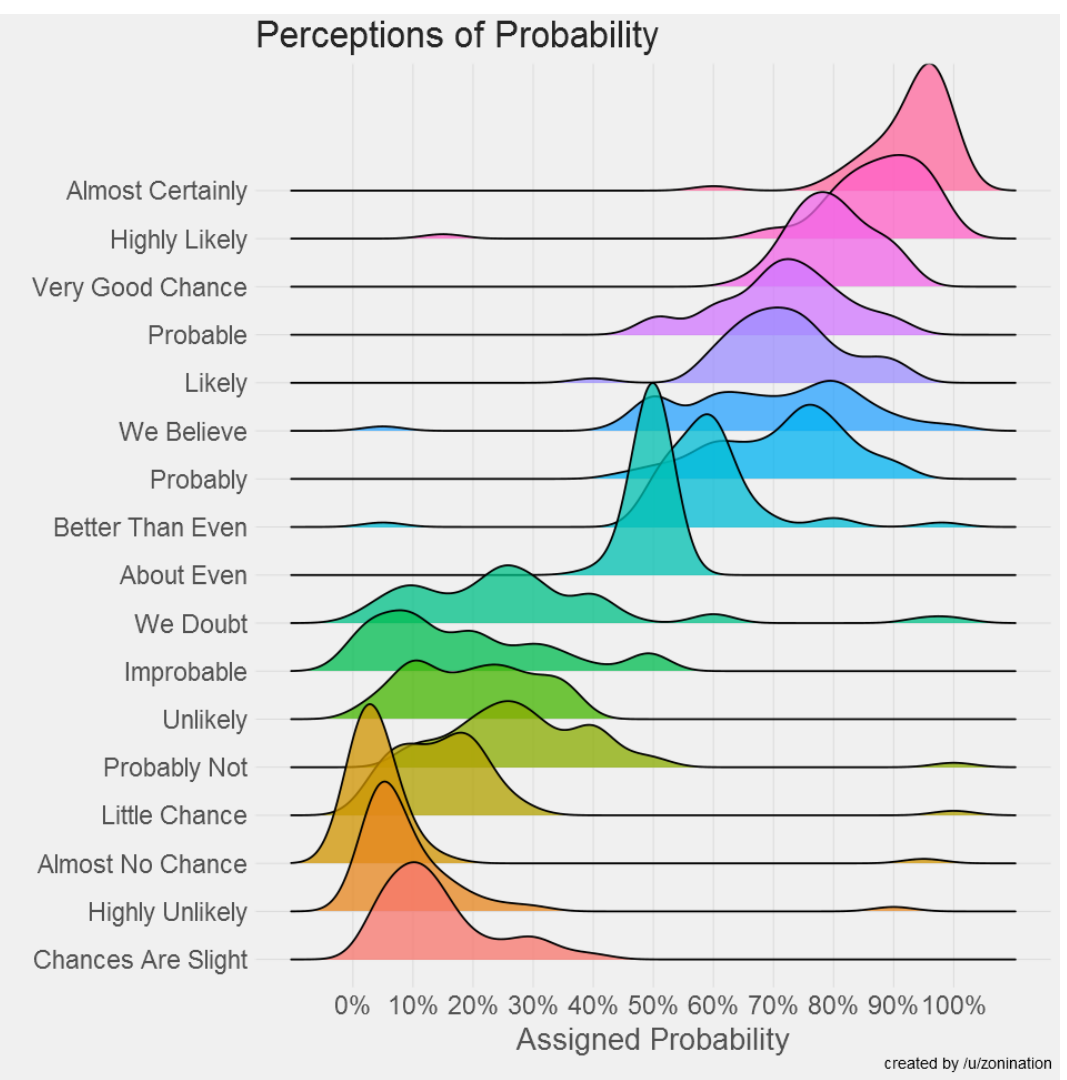

Fig. 1. Perception of Probability: Study of the Sherman-Kent School, USA

Table 1. Fact versus opinion

\begin{tabular}{|l|l|l|}
\hline \multicolumn{1}{|c|}{ Reference } & \multicolumn{1}{c|}{ Fact } & \multicolumn{1}{c|}{ Opinion } \\
\hline Type of text & $\begin{array}{l}\text { Piece of information presented } \\
\text { as having objective reality }\end{array}$ & View or judgment about something \\
\hline Verifiability & Can be proved or verified with evidence & Cannot be proved with evidence \\
\hline Objectivity & Objective and neutral & Personal and subjective \\
\hline Changeability & Does not change & May differ according to different people \\
\hline
\end{tabular}

\section{Corpora for the «highly-likely» study}

The best instruments to investigate the character of «highly-likely» phrase can be provided by modern corpora means and opportunities. For this small research, large resources of the five modern corpora were used:

1. The British National Corpus (BYUBNC), a completed project, a famous 100-million electronic collection of samples of modern British English of a wide range of genres from the later part of the $20^{\text {th }}$ century.
2. The iWeb corpus, the largest collection containing 14 billion words in 22 million webpages. Chosen for a large amount of recent data.

3. CORE: Corpus of Online Registers of English which contains more than 50 million words of text from the web. Unlike other corpora from the web, which are just big «blobs» of data, this is the first large web-based corpus that is carefully categorized into many different registers. 
4. The Corpus of Contemporary American English (COCA) is the largest freelyavailable corpus of English, and the only large and balanced corpus of American English. COCA contains more than 560 million words of text, 20 million words each year 1990-2017, and is probably the most widely-used corpus of English.

5. The British Law Report Corpus (BLaRC), an 8.85 million-word legal corpus of 1,228 judicial decisions issued between 2008 and 2010 by British courts and tribunals. The BLaRC is structured into five main sections reflecting the different jurisdictions of the British judicial system. Chosen as a special corpus, fundamental for identification of the specialised vocabulary of the legal English genre.

To get a clearer sense, we need to apply to detailed study of the corpora transcripts, in conjunction with some basic techniques such as keyword listing, frequency analysis and concordancing. All the five corpora give a representative amount of «highly-likely» entries, with salient 13,492 instances in the largest corpus (Table 2).

Numerous examples of "highly-likely» entries ranging across degrees of probability or certainty shed light on how appreciation of what is reported can be created or constrained in different situations, as well as on pragmatic functions of the hedging device:

1) «... the United States in the late 1960s consistently opposed an increase in the official price of gold. It is highly likely that there was no possible adjustment to the gold price in the 1960s which would have ensured an adequate flow of gold into the reserves of the USA and other countries.» (Source: BNC, retrieved from
Harrison, J. et al. Capitalism since 1945. Oxford: Blackwell, 1991).

Possible pragmatic function: the author expressed uncertainty and imprecision when the precise information was not available.

2) «... as Eisenhower later publicly admitted, on 17 March Washington took the decision to prepare an invasion of Cuba (The New York Times, 13 June 1961, p. 18). Whilst there is no conclusive proof, it seems highly likely that this piece of information would have reached Castro's ears soon after.» (Source: BNC, retrieved from Miller, N. Soviet relations with Latin America. Cambridge: CUP, 1989) «No conclusive proof» does not expect confirmed truth.

"Whilst there is no conclusive proof» tells about lack of information, the author demonstrates imprecision.

3) «Scotland's first minister has said a second independence referendum is "highly likely" after the UK voted to leave the EU.» (Source: $i W e b$, retrieved from https://www.bbc.com/news/ $u k$-scotland-scotland-politics-36621030).

The minister mitigates direct criticism and incitement.

4) "It is highly likely that the decision of the governors of Altrincham Grammar School for Girls to suspend two Muslim girls who wished to wear head scarves to school for being in breach of school uniform rules would also have been unlawful.» (Source: BNC, retrieved from Johnstone, $S$. et al. The legal context of teaching. UK, Longman, 1992).

The pragmatic function is as in sample 3 .

5) «The whole plot would have been vastly over elaborate, required far too many people in on it and would have been highly likely to go

Table 2. Representation of «highly-likely» phrases in selected corpora

\begin{tabular}{|l|l|l|l|}
\hline Corpus & Size in words & \multicolumn{1}{|c|}{ Issue years } & \multicolumn{1}{c|}{ Size in «highly-likely» entries } \\
\hline BNC & $100 \mathrm{mln}$ & $1880 \mathrm{~s}-1993$ & 70 \\
\hline iWeb & $14 \mathrm{bln}$ & $\begin{array}{l}\text { released in May } \\
2018, \text { ongoing }\end{array}$ & 13,492 \\
\hline CORE & $50 \mathrm{mln}$ & $2013-2016$ & 94 \\
\hline COCA & $500 \mathrm{mln}$ & $1990-$ ongoing & 259 \\
\hline BLaRC & $8.85 \mathrm{mln}$ & $2008-2010$ & $\begin{array}{l}735 \text { documents matched the query, both likely } \\
\text { and highly likely }\end{array}$ \\
\hline
\end{tabular}


wrong.» (Source: CORE, retrieved from http:// www.bbc.co.uk/blogs/theeditors/2008/10/caught_ up_in_a_conspiracy_theo.html).

Possible pragmatic function: avoiding the author's direct involvement.

6) «Nicola Sturgeon, Scotland's first minister, said on Friday that a new referendum on independence in Scotland was "highly likely» now that Britain has voted to leave the European Union. Voters rejected an effort to break free from the United Kingdom in a 2014 referendum, but Ms. Sturgeon said Scotland would take measures to protect its place in Europe and maintain access to the single market》 (Source: COCA, retrieved from New York Times, 201606-24).

Possible pragmatic function: the minister reduces the risk of opposition.

Some instances add factual information to the contexts, thus complimenting to higher degree of certainty:

1) "Children in their study who had experienced a sexual assault of any kind also were highly likely (97\%) to have been victimized in other ways, such as physical assault, witnessing the assault of another, child maltreatment, and having their property damaged or stolen.» (Source: COCA, retrieved from Brown S., et al. Traumatic Symptoms in Sexually Abused Children: Implications for School Counselors. USA: Professional School Counseling, 2018, Vol. 11).

2) «When asked whether special education teachers who meet highly qualified requirements are better prepared and more skillful at teaching core academic content than teachers who do not meet those requirements, respondents differed in their perceptions. Teacher educators $(n=13)$ were most likely to agree with that statement (84\% of respondents). Administrators ( $n=101)$ were also highly likely to agree with that statement (74\% of respondents). Teachers $(n=184)$ were less likely to agree with that statement (52\% of respondents).» (Source: COCA, retrieved from Rural Special Education Quarterly, 2010, Vol. 29. Issue 3).

\section{«Highly likely» in legal discourses}

Interestingly, highly likely devices turn to be common in the British legal discourses which refer to the acts of communication used in the practice of law and are meant to be as objective as possible. The British Law Report Corpus (BLaRC) gives many instances of this type from the court judgments, court decisions on pre-hearing reviews, opinions of the lords of appeal for judgment in the cause, etc.:

1) "This is highly likely to be a psychotic experience, namely an auditory hallucination.»

2) "In all the circumstances it was therefore highly likely the Pursuer, he suggested, would have told the Defenders of his injury when discussing the defect that caused said accident.»

3) "Given the nature of the offence, it is highly likely that there will be admissible evidence of the offence.»

4) "However, it is highly likely that she is shouldering some of the responsibility for the Defendant's sexual abuse.»

5) «It is highly likely that, together with a guilty plea and in mitigation, the Defendant will express remorse and shame for what he has done to $B$. He is unlikely to give any evidence in the criminal proceedings and is, therefore, unlikely to be challenged.»

6) «I accept that it is highly likely that JB was chaotically abusing heroin at the time at which JJ suffered his injuries.»

(Source: BLaRC, all retrieved from http://flax.nzdl.org/greenstone3/flax? $a=$ $f p \& s a=$ collAbout\& $c=$ BlaRC\&if $=$ ).

It is often believed that legal discourses are factual, they convey facts via direct language. However, imaginary "This is a psychotic experience, namely an auditory hallucination» instead of the first instance or «I accept that JB was chaotically abusing heroin at the time at which $J J$ suffered his injuries»for the sixth go beyond the scope of norms of the legal language. It is well-regarded that an important feature of a legal discourse is the concept of cautious or vague language. In other words, the actors have to make decisions about their stance on a particular subject, or the strength of the claims they make. Different subjects prefer to do this in different ways, and highly likely language patterns are very convenient hedging devices in «strengthening the arguments by weakening the claims» (Taweel et al., 2011: 173). In all the six instances the authors are either express and show politeness $(1,2,4$, $6)$, or modify the discourse $(1,3,5)$. 


\section{Subjectivity}

of highly likely patterns

A pattern is essentially repetition (Hunston, 2012: 152). Recognising a pattern itself a «tricky exercise» (Scott, 2012: 140) and includes manual extracting sought concordance strings. In the wide range of different patterns in the corpora mentioned above, the case of very/highly likely phrases were frequent enough to be easily recognised and retrieved. Examples of this pattern, illustrating the degree of probability, would include:

It seems very likely (that) ...

It seems highly likely (that) ...

It looks highly likely (that) ...

It looks very unlikely (that) ...

Generally, «it seems/looks» phrase is used to underline that someone thinks that something is true:

1) «Despite the unforgivable reticence of the Government to make any commitment on the future of EU nationals, it still seems highly likely that generous transitional arrangements will be made if the UK does not join the EEA.» (Source: $i W e b$, retrieved from https://www.freemovement.org.uk/brexitwhat-should-eea-and-eu-nationals-andtheir-family-members-do-now/).

2) «There are no records that confirm that Constable visited the gallery, but it seems highly likely that during his extended stays in Brighton in the 1820s he would have dropped in to see the impressive display of high quality art.» (Source: $i$ Web, retrieved from http://brightonmuseums. org.uk/discover/2017/05/04/john-constable-and- brightons-beautiful-and-splendid-cabinet-ofthe-arts/).

3) "In next year's national elections, with dissatisfaction growing and Merkel's popularity waning, it looks highly likely they could cross that 5 per cent threshold.» (Source: iWeb, retrieved from http://blogs.spectator.co.uk/2016/09/ alternative-fur-deutschland-forced-germanpolitics-right/).

4) "Whilst there is no conclusive proof, it seems highly likely that this piece of information would have reached Castro's ears soon after.» (Source: BNC, retrieved from Miller, N. Soviet relations with Latin America. Cambridge: CUP, 1989).

Observing the pattern in this set of examples involves perceiving a higher level of subjectivity in each statement.

\section{Conclusion}

In the preceding examples retrieved from modern political, legal and social media discourses, an attempt has been made to identify «highly likely» phrases, and detect their pragmatic functions and anthropological backgrounds. Regardless of the large speculations and insights into «new» type of official language, caused by Scripal case, it should be acknowledged that hedging has been a common strategy to express both facts and opinions indirectly. By hedging, speakers tone down statements - facts and opinions - to avoid direct incitement or criticism, to reduce the risk of opposition, to mitigate claims, to avoid hurting others and express politeness, to request the receivers' involvement.

\section{References}

Bruce, F. (2010). Hedging in political discourse: The Bush 2007 press conferences. In Okulska, Urszula \& Cap, Piotr (Eds.). Perspectives on Politics and Discourse, 36, 201-214. Amsterdam/ Philadelphia: John Benjamins Publishing Company.

Crystal, D. (1997). The Cambridge Encyclopedia of Language. UK: Cambridge University Press.

Duranti. A. (2002). Linguistic Anthropology. In International Encyclopedia of the Social and Behavioral Sciences. Oxford: Elsevier, 8899-8906.

Feller, W. (1968). An Introduction to Probability Theory and Its Applications. USA: John Wiley \& Sons.

Hunston, S. (2012). How can a corpus be used to explore patterns? In O'Keeffe, A., McCarthey, M. (Eds.). The Routledge Handbook of Corpus Linguistics. UK, Routledge, 152-166.

Jaynes, E.T. (2003). Probability Theory: The Logic of Science. UK, Cambridge University Press.

Kerrich, J. (1946). An experimental introduction to the theory of probability. Denmark, E. Munksgaard. 
Lakoff, G. (1972). Hedges: A study in meaning criteria and the logic fuzzy concepts. Chicago Linguistic Society papers, 8, 183-228.

Lavrov, S. (July 2018). Foreign Minister Sergey Lavrov's interview with Larry King's «Politicking» show on RT, Moscow, Available at: http://www.mid.ru/en/web/guest/meropriyatiya_s_uchastiem_ministra/-/asset_publisher/xK1BhB2bUjd3/content/id/3294860

Lavrov, S. (March 2018). Sergey Lavrov's interview with BBC HardTalk. Available at: http://www. mid.ru/en/web/guest/organizacia-po-zapreseniu-himiceskogo-oruzia/-/asset_publisher/km9HkaXMTium/ content $/ \mathrm{id} / 3172318$

Lavrov, S. (May 2018). Foreign Minister Sergey Lavrov's interview with the Argentine newspaper Clarin. Available at: http://www.mid.ru/en/web/guest/foreign_policy/news/-/asset_publisher/cKNonkJE02Bw/content/id/3229090

Maksimov, B. (2018). Highly likely: kak britanskiy angliyskiy zaputyvaet inostrantsev [Highly likely: how British English confuses foreigners]. Available at: https://www.bbc.com/russian/features-43804414

Miles, J. (2018). «Highly Likely». Available at: http://www.greanvillepost.com/2018/04/05/highlylikely/

Mitchell, A., Gottfried, J., Barthel, M., and Sumida, N. (2018). Distinguishing between factual and opinion statements in the news. USA, Pew Research Center.

Palmer, F.R. (1979). Modality and the English modals. UK, Longman.

Palmer, F.R. (2001). Mood and Modality, UK, Cambridge University Press.

Perceptions of probability and numbers (2018). The Sherman-Kent School, USA. Available at: https://github.com/zonination/perceptions

PM Commons statement on Salisbury incident: 12 March 2018. Government of the United Kingdom.

Romero-Trillo, J. (2014). Istvan Kecskes: Intercultural Pragmatics. In Applied Linguistics, 35 (5), $621-$ 624.

Russian spy: Highly likely Moscow behind attack, says Theresa May (2018). Available at: https://www. bbc.com/news/uk-43377856

Sahoo, P. (2013). Probability and mathematical statistics. Louisville, University of Louisville, USA.

Scott, M. (2012). What can corpus software do? In O'Keeffe, A., McCarthey, M. (Eds.) The Routledge Handbook of Corpus Linguistics. UK, Routledge, 136-151.

Taweel, A.Q., Saidat, E.M.R., Hussein, A. \& Saidat, A.M. (2011). Hedging in Political Discourse. In The Linguistic Journal, 5 (I.1), 169-196.

The British Law Report Corpus (BLaRC). Available at: http://flax.nzdl.org/greenstone3/flax?a=f$\mathrm{p} \& \mathrm{sa}=$ collAbout $\& \mathrm{c}=\mathrm{BlaRC} \& \mathrm{if}=$

The British National Corpus. Available at: https://corpus.byu.edu/bnc/

The Corpus of Contemporary American English. Available at: https://corpus.byu.edu/coca/

The Corpus of Online Registers of English. Available at: https://corpus.byu.edu/core/

The iWeb corpus. Available at: https://corpus.byu.edu/iweb/

Voronin, N. (2018). \#HighlyLikelyRussia. In Facebook. Available at: https://www.facebook.com/voronin/posts/10156370689997941 